\title{
ANALISIS KEPUASAN PELAYANAN PERGURUAN TINGGI (Kasus pada Prodi Magister Pendidikan Ekonomi Unnes)
}

\author{
Kardoyo dan Ahmad Nurkhin \\ Fakultas Ekonomi Universitas Negeri Semarang \\ email: kardoyo_unnes@yahoo.co.id
}

\begin{abstract}
Abstrak: Fokus penelitian ini adalah pengukuran kepuasan pelayanan terhadap mahasiswa, penelusuran lulusan, dan kepuasan pengguna lulusan. Populasi penelitian adalah mahasiswa Prodi Magister Pendidikan Ekonomi PPs Unnes yang aktif pada semester gasal 2015/2016, lulusan, dan pengguna lulusan. Alat yang digunakan adalah instrumen SERVQUAL yang dikembangkan dari Parasuraman et al. (1994) untuk mengukur kepuasan mahasiswa. Instrumen pengukuran kesesuaian lulusan dan kepuasan pengguna lulusan berdasarkan pedoman akreditasi BAN PT. Analisis data dilakukan dengan analisis statistik deskriptif dan importance-performance analysis (IPA). Hasil penelitian menunjukkan bahwa berdasarkan analisis kepuasan layanan terdapat dua dimensi layanan yang harus menjadi prioritas utama untuk segera diperbaiki, yaitu dimensi acces dan reliability. Hasil lainnya menunjukkan bidang pekerjaan alumni telah sesuai dengan visi misi prodi dan alumni berpendapat materi dan proses perkuliahan sangat relevan dengan bidang pekerjaan yang digeluti sekarang sehingga sangat membantu menyelesaikan pekerjaan. Terakhir, kepuasan pengguna terhadap kompetensi lulusan termasuk dalam kategori sangat bagus.
\end{abstract}

\section{Kata kunci : mahasiswa, lulusan, pengguna lulusan, kualitas layanan,Importance-Performance Analysis}

\section{ANALYSIS TOWARDS UNIVERSITIES' SERVICES SATISFACTION}

\begin{abstract}
The study focuses on the measurement of satisfaction withstudent services, tracer study and stakeholder satisfaction. The study population is students of Economics Education Master Program of PPs Unnes in the odd semester of 2015/2016, graduates and stakeholders. SERVQUAL instrument developed by Parasuraman et al. (1994) is employed to measure student satisfaction. The compatibility between the graduate and stakeholder satisfaction is measured based on BAN PT accreditation guidelines. Data were analyzed using descriptive statistical analysis, and the Importance-Performance Analysis (IPA). The results show that, in terms of service satisfaction analysis, two dimensions of service should be improved immediately, i.e. access and reliability. It has also been revealed that the fields of alumni's job have been in accordance with the vision and mission of the study program and that the material and lecture have been highly relevant to their field of work. Lastly, stakeholders are found to be highly satisfied with graduate competencies.
\end{abstract}

Keywords: students, stakeholder, servicequality, Importance-Performance Analysis

\section{PENDAHULUAN}

Penyelenggaraan pendidikan saat ini dituntut dapat memberikan pelayanan yang berkualitas bagi pelanggannya. Kualitas pelayanan mencerminkan kualitas manajemen pendidikan. Rifandi (2013:125) menyatakan bahwa Pendidikan Tinggi merupakan salah satu pilar penting dalam pembangunan suatu bangsa. Sebagai jenjang pendidikan paling tinggi dalam sistem pendidikan nasional, pendidikan tinggi menjadi ujung tombak dalam mendorong perkembangan suatu bangsa. Supriyanto (2011:17) mengemukakan bahwa berbagai upaya untuk meningkatkan kualitas pendidikan tinggi telah, sedang, dan akan terus dilaksanakan. Strategi pengembangannya antara lain dilakukan dengan menerapkan paradigma baru berupa peningkatan kualitas berkelanjutan di masa mendatang yang dikenal Total Quality Management (TQM). Ramseook-Munhurrun et al. (2010) dan Silva and Fernandes (2012) mengemukakan bahwa studi tentang kualitas pelayanan di dunia pendidikan telah meningkat perhatiannya seiring dengan permintaan pasar atas pendidikan yang berkualitas. 
Jain et al. (2011) mengemukakan bahwa institusi akademik membutuhkan inovasi berkelanjutan, diversitas struktur, dan menemukan cara baru untuk memberikan pelayanan kepada pelanggannya secara lebih efektif. Hal ini ditujukan untuk memperoleh keuntungan kompetitif dengan institusi akademik lainnya. Caranya adalah dengan lebih memahami kepuasan pelanggan dan persepsi pelanggan atas kualitas pelayanan yang diberikan dan yang telah dirasakan. Namun demikian, Sharabi (2013) berpendapat bahwa perguruan tinggi masih belum memberikan perhatian dalam pelayanan kepada pelanggan. Perguruan tinggi harus lebih efisien dan berpartisipasi dalam persaingan global yang kompetitif dimana ekspektasi pelanggannya semakin meningkat. Trivellas and Dargenidou (2009) mengkaitkan kepemimpinan dengan kualitas pelayanan. Kepemimpinan di perguruan tinggi harus mampu menciptakan budaya pelayanan sehingga karyawan mempunyai kinerja yang maksimal melalui komunikasi yang baik, motivasi dan penyediaan kesempatan bagi karaywan untuk berkembang.

Konsep kualitas pelayanan yang diterapkan di perusahaan mulai digunakan dalam penyelenggaraan pendidikan tinggi seperti pelayanan prima, TQM, dan konsep lainnya. Namun demikian, Primiani dan Ariani (2005:178) berpendapat bahwa kualitas pelayanan di dunia pendidikan memunyai karakter khusus dan lebih sulit daripada pelayanan pada produk yang berwujud. Organisasi pendidikan adalah penghasil jasa yang diharapkan masyarakat untuk mewujudkan kualitas sumber daya manusia melalui sistem dan hasil pendidikan yang berkualitas. Lebih lanjut ia mengungkapkan bahwa pelanggan pada organisasi pendidikan sangat berbeda dengan karakter pelanggan pada produk korporasi. Pelanggan pada lembaga pendidikan mempunyai karakter yang berbeda, yaitu mempunyai fungsi yang unik dalam menentukan mutu dari apa yang mereka terima dari dunia pendidikan.

Program studi Magister Pendidikan Ekonomi PPs Unnes berdiri pada tahun 2011 dan memperoleh nilai akreditasi B pada tahun 2013. Prodi tersebut terus mengalami perkembangan dalam kualitas pelayanan pendidikan yang diselenggarakan. Kegiatan pengembangan prodi terintegrasi dengan program pencapaian visi misi PPs Unnes. Perkembangan prodi dapat dilihat dari perkembangan jumlah mahasiswa yang diterima dari tahun 2011-2015, yaitu 13 mahasiswa pada angkatan pertama dan 29 pada angkatan kelima.
Jumlah mahasiswa mengalami peningkatan yang signifikan, khususnya pada tahun 2014. Jumlah lulusan adalah 24 orang (baru $50 \%$ pada dua angkatan pertama). Artinya, masih membutuhkan program khusus untuk memberikan dorongan kepada mahasiswa untuk segera menyelesaikan studi.

Kenyataan yang ada tersebut memberikan arti bahwa Prodi harus melaksanakan kegiatan perbaikan dan pengembangan. Pertama, terkait dengan mahasiswa sebagai pelanggan. Dalam hal ini, prodi harus bisa menangkap sejauh mana tingkat kepuasan yang dirasakan. Hal ini penting untuk menjadikan "pelanggan" sebagai sarana promosi prodi ke calon mahasiswa baru. Jika mahasiswa mengalami kepuasan yang positif, hal itu akan membuat informasi positif bagi masyarakat secara umum khususnya calon mahasiswa. Hasil penelitian Dirwan (2014:389) menunjukkan bahwa terdapat pengaruh dari kualitas pelayanan terhadap motivasi berprestasi mahasiswa.

Alat yang akan digunakan untuk mengukur kepuasan pelanggan (khususnya layanan akademik dan administratif) adalah ImportancePerformance Analysis (IPA) yang dikembangkan oleh Martilla \& James (1977). Kualitas layanan dapat diukur dengan menggunakan instrumen SERVQUAL dikembangkan dari Parasuraman et al. (1994), (Algifari, 2015). Ramseook-Munhurrun et al. (2010) mengembangkan EDUSERV untuk mengukur kualitas pelayanan dalam setting dunia pendidikan. Metode ini diharapkan mampu memberikan evaluasi secara komprehensif terhadap kualitas layanan akademik dan administratif di podi Magister Pendidikan Ekonomi PPs Unnes. Banyak penelitian yang telah membuktikan kegunaan metode IPA ini di antaranya adalah Angell et al. (2008), Brochado (2009), Muzakiyah (2011), Silva and Fernandes (2012), dan Ong dkk. (2014).

Kedua, terkait dengan lulusan dan pengguna lulusan. Penelusuran alumni perlu dilakukan lagi untuk memperoleh informasi tentang lulusan dan pengguna lulusan. Informasi ini sangat penting bagi prodi untuk memperoleh data kesesuaian kerja lulusan dan juga tingkat kepuasan pengguna lulusan. Penelusuran alumni atau tracer study dapat menggunakan instrumen yang dikembangkan dari pedoman akreditas prodi S2 yang dikeluarkan oleh Kemenristekdikti sehingga informasi yang akan diperoleh menjadi relevan dengan kegiatan akreditasi prodi. 
Fokus penelitian ini adalah pengukuran kepuasan pelanggan (mahasiswa), penelusuran lulusan, dan pengukuran kepuasan pengguna lulusan. Penelitian ini ditujukan untuk memberikan informasi penting dalam menggambarkan kualitas pelayanan yang diharapkan dan kualtias pelayanan yang diterima oleh mahasiswa. Dan digunakan untuk menelusur lulusan dan kepuasan pengguna lulusan.

Supranto (2006:237) mengemukakan bahwa kualitas adalah sebuah kata yang bagi penyedia jasa merupakan sesuatu yang harus dikerjakan dengan baik. Definisi dari pelayanan itu sendiri adalah upaya maksimal yang diberikan oleh petugas pelayanan dari sebuah perusahaan industri untuk memenuhi harapan dan kebutuhan pelanggan sehingga tercapai kepuasan. Parasuraman et al. (1994) menyatakan bahwa layanan atau service didefinisikan sebagai aktifitas ekonomi yang memproduksi waktu, tempat, form atau kegunaan psikologis. Selanjutnya, bahwa kualitas layanan adalah persepsi pelanggan terhadap keunggulan suatu layanan. Hanya pelanggan yang menilai kualitas layanan suatu perusahaan berkualitas atau tidak.

Dimensi kualitas layanan menurut Parasuraman, et al. (1994) terdapat lima dimensi penting yang menentukan tingkat service quality yaitu: (a) dimensi Tangible (bukti langsung) adalah penampilan fisik, peralatan, dan sarana komunikasi; (b) dimensi Reliability (keandalan) adalah kemampuan untuk melaksanakan jasa sesuai yang telah dijanjikan secara akurat dan dapat diandalkan; (c) dimensi Responsiveness (daya tanggap) yaitu kesediaan untuk membantu pelanggan dan memberikan layanan seketika; (d) dimensi Assurance (jaminan) adalah pengetahuan, sopan santun, dan kemampuan karyawan untuk menimbulkan rasa percaya dan keyakinan; dan (e) dimensi Empathy (kepedulian) adalah rasa peduli dan perhatian individual yang diberikan perusahaan kepada pelanggan.

Lupiyoadi dan Hamdani (Sudirman, 2010) menyatakan bahwa karakteristik jasa pada perguruan tinggi antara lain sebagai berikut.

a) Perguruan tinggi termasuk ke dalam kelompok jasa murni, dimana pemberian jasa yang dilakukan didukung alat kerja atau sarana pendukung semata. Contoh ruangan kelas, kursi, meja, buku buku dan sebagainya.

b) Jasa yang diberikan membutuhkan kehadiran pengguna jasa (mahasiswa), dalam hal ini pelanggan yang mendatangi lembaga pendidikan tersebut untuk mendapatkan jasa yang diinginkan.

c) Penerima jasanya adalah orang. Jadi merupakan jasa yang berbasis orang. Atau di dalam jasa biasa disebut kontak tinggi yaitu hubungan antara pemberi jasa dengan pelanggan tinggi.

d) Hubungan dengan pelanggan berdasarkan hubungan keanggotaan, dimana pelanggan telah menjadi anggota lembaga pendidikan tertentu. Sistem pemberian jasanya dilakukan secara terus menerus dan teratur sesuai dengan kurikulum yang telah ditetapkan.

Teknik Importance-Performance Anaylisis (IPA) dikemukakan oleh Martilla \& James (1977) dalam artikel mereka "Importance-Performance Analysis" yang dipublikasikan di Journal of Marketing (Algifari, 2015). Martilla dan James (1977) memperkenalkan Importance-Performance Analysis (IPA) yang merupakan model multi-attribute dan dapat digunakan untuk menganalisis kinerja organisasi. Model IPA digunakan untuk mengukur kinerja kepuasan yang dianggap penting oleh pelanggan dan kinerja kepuasan yang diterima oleh pelanggan. Tujuan utama IPA adalah sebagai alat mendiagnostik untuk memudahkan mengidentifikasi atribut-atribut yang didasarkan pada kepentingannya masing-masing. Untuk tujuan tersebut, inteprestasi terhadap kinerja produk atau jasa ditampilkan pada sebuah grafik yang memiliki empat kuadran, yaitu Kuadran A, Kuadran B, Kuadaran C, dan Kuadran D. Masing-masing kuadran menunjukkan kinerja produk atau jasa yang dinilai.

Kuadran A menggambarkan bahwa pelanggan menganggap atribut tersebut penting sehingga pelanggan memiliki harapan yang tinggi pada atribut tersebut. Akan tetapi, perusahaan tidak memberikan pelayanan yang baik terhadap atribut ini. Kuadran A mengisyaratkan perusahaan harus berkonsentrasi untuk memperbaiki kinerjanya pada atribut ini (concentrate here). Kuadran B menggambarkan atribut yang dianggap penting bagi pelanggan, sementara perusahaan sudah memberikan pelayanan yang baik kepada pelanggan untuk atribut ini. Dengan demikian, pelayanan yang diberikan pada atribut di kuadran B ini perlu dipertahankan (keep up the good work). Kuadran $\mathrm{C}$ pada model IPA menggambarkan atribut yang diangggap tidak penting oleh pelanggan dan perusahaan memberikan pelayanan yang rendah 
kepada pelangan untuk atribut ini. Oleh karena itu, perusahaan memberikan prioritas yang rendah pada atribut tersebut (low priority). Kuadran D menggambarkan wilayah aribut yang memiliki kepentingan rendah bagi pelanggan, akan tetapi perusahaan memberikan pelayanan yang baik kepada pelanggan. Oleh karena itu, daerah ini disebut daerah berlebih (possible overkill). Gambar 1 berikut ini merupakan bentuk asli dari diagram derajat kartesius model IPA yang dikembangkan oleh Martilla dan James.

\begin{tabular}{|c|c|}
\hline $\begin{array}{c}\text { Kuadran A } \\
\text { Prioritas Utama }\end{array}$ & $\begin{array}{c}\text { Kuadran B } \\
\text { Pertahankan Prestasi }\end{array}$ \\
\hline $\begin{array}{c}\text { Kuadran C } \\
\text { Prioritas Rendah }\end{array}$ & $\begin{array}{c}\text { Kuadran D } \\
\text { Berlebihan }\end{array}$ \\
\hline
\end{tabular}

\section{Gambar 1. Kuadran Model}

Importance-Performance Analysis

Sumber: Martilla, J and James, J. (1977). ImportancePerformance Analysis. Journal of Marketing.

\section{METODE}

Penelitian ini merupakan penelitian kuantitatif dengan desain deskriptif dan uji komparasi. Penelitian ditujukan untuk mengukur kepuasan mahasiswa prodi Magister Pendidikan Ekonomi PPs Unnes antara yang diharapkan (importance) dan yang diterima (perceived) oleh mahasiswa, penelusuran lulusan, dan mengukur kepuasan pengguna lulusan. Penelitian dilakukan selama lima bulan, yaitu pada bulan Juli-November 2015. Populasi penelitian adalah seluruh mahasiswa, lulusan, dan pengguna lulusan prodi Magister Pendidikan Ekonomi PPs Unnes.

Data yang digunakan adalah data primer yang diperoleh dengan menggunakan alat berupa kuesioner. Instrumen yang digunakan untuk mengukur kepuasan mahasiswa adalah merujuk pada konsep SERVQUAL yang dikembangkan oleh Parasuraman et al. (1994), (Algifari (2015). Kualitas pelayanan terdiri dari lima dimensi yaitu: ketersediaan fisik (tangibles), ketepatan pelayanan (reliability), kemauan dan kesiapan memberikan pelayanan (responsiveness), pemahaman dan sikap sopan (assurance), dan pemahaman terhadap kebutuhan penerima layanan (emphaty). Instrumen digunakan untuk mengukur kesesuaian lulusan dan kepuasan pengguna lulusan adalah berdasarkan pedoman akreditasi dari BAN PT.
Analisis data menggunakan analisis statistik deskriptif dan analisis dengan metode importance-performance analysis (IPA). Analisis statistik deskriptif ditujukan untuk mendeskripsikan kepuasan mahasiswa, kesesuaian lulusan, dan kepuasan pengguna lulusan. Analisis dilakukan dengan menggunakan software SPSS 16.

\section{HASIL DAN PEMBAHASAN Deskripsi Kepuasan Mahasiswa dengan Me- tode IPA}

Indeks kepuasan mahasiswa diukur untuk mengetahui tingkat kepuasan yang diterima mahasiswa Magister Pendidikan Ekonomi Unnes dalam hal layanan administratif. Kepuasan layanan mahasiswa diukur dalam lima dimensi layanan, yaitu tangible, reliability, responsiveness, assurance, dan emphaty. Dimensi assurance dibagi lagi menjadi tiga sub dimensi, yaitu competence, credibility, courtesy, dan security. Dimensi emphaty terbagi menjadi tiga subdimensi yaitu acces, communication, dan understanding customer. Hasilnya menunjukkan bahwa mahasiswa sudah menganggap memuaskan atas layanan yang mereka terima, walaupun nilainya mendekati kurang memuaskan. Indeks kepuasan hanya sebesar 2,51 atau 62,67 secara rata-rata, sedang data yang lain ditunjukkan pada Tabel 1.

Kepuasan mahasiswa juga dihitung melalui persentase kualitas yang telah diterima mahasiswa. Hasil perhitungan yang menunjukkan bahwa persentase kepuasan mahasiswa sebesar $62,65 \%$, ini masih tergolong rendah. Artinya, mahasiswa masih menganggap kurang puas terhadap layanan yang diterima. Walaupun demikian, secara ratarata mahasiswa berpendapat bahwa layanan yang mereka terima adalah memuaskan.

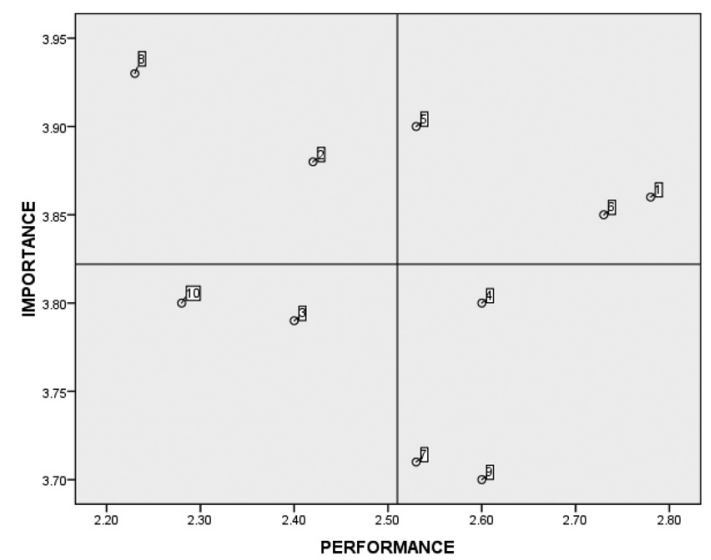

Gambar 2. Hasil Analisis Kepuasan Layanan dengan IPA 
Tabel 1. Indeks Kepuasan Mahasiswa

\begin{tabular}{clcccl}
\hline No. & Dimensi Pelayanan & Importance & Performance & $\begin{array}{c}\text { Kepuasan } \\
\text { Konversi }\end{array}$ & $\begin{array}{l}\text { Kategori } \\
\text { Kepuasan }\end{array}$ \\
\hline 1 & Tangible & 3.86 & 2.78 & 69.38 & Memuaskan \\
2 & Reliability & 3.86 & 2.42 & 60.42 & $\begin{array}{l}\text { Kurang } \\
\text { Memuaskan }\end{array}$ \\
3 & Responsiveness & 3.79 & 2.40 & 60.00 & Kurang \\
& & & & Memuaskan \\
4 & Competence & 3.80 & 2.60 & 65.00 & Memuaskan \\
5 & Credibility & 3.90 & 2.53 & 63.13 & Memuaskan \\
6 & Courtesy & 3.85 & 2.73 & 68.13 & Memuaskan \\
7 & Security & 3.71 & 2.53 & 63.13 & Memuaskan \\
8 & Acces & 3.93 & 2.23 & 55.63 & Kurang \\
& & & & & Memuaskan \\
9 & Communication & 3.70 & 2.60 & 65.00 & Memuaskan \\
10 & Understanding Customer & 3.80 & 2.28 & 56.88 & Kurang \\
& & & & & Memuaskan \\
\hline & Rata-rata & $\mathbf{3 . 8 2}$ & $\mathbf{2 . 5 1}$ & $\mathbf{6 2 . 6 7}$ & Memuaskan \\
\hline
\end{tabular}

Kepuasan layanan menggunakan Importance-Performance Analysis tampak pada gambar 2 berikut ini. Hasil analisis IPA adalah sebagai berikut.

1. Pada kuadran A terdapat dua dimensi, yaitu dimensi 8 (acces) dan dimensi 2 (reliability). Artinya kedua dimensi tersebut dianggap penting oleh mahasiswa namun prodi Pendidikan Ekonomi S2 Unnes memberikan layanan dengan kualitas yang buruk. Dengan demikian, kedua dimensi ini harus menjadi prioritas utama untuk diperbaiki.

2. Pada kuadran B terdapat tiga dimensi, yaitu dimensi 5 (courtesy), dimensi 6 (credibility), dan dimensi 1 (tangible). Artinya, ketiga dimensi tersebut dianggap penting oleh mahasiswa dan prodi Pendidikan Ekonomi S2 telah memberikan layanan dengan kualitas yang baik sehingga ketiga dimensi ini harus dipertahankan prestasinya.

3. Pada kuadran $\mathrm{C}$ terdapat dua dimensi, yaitu dimensi 10 (understanding the customer) dan dimensi 3 (responsiveness). Artinya, kedua dimensi ini dianggap kurang penting oleh mahasiswa tetapi prodi Pendidikan Ekonomi S2 telah memberikan layanan dengan kualitas rendah. Dengan demikian, kedua dimensi ini menjadi prioritas rendah untuk diperbaiki.

4. Pada kuadran D terdapat tiga dimensi, yaitu dimensi 7 (security), 4 (competence), dan 9 (communication). Artinya, ketiga dimensi tersebut kurang dianggap penting oleh mahasiswa tetapi prodi Pendidikan Ekonomi S2 telah memberikan layanan dengan kualitas baik. Sehingga ketiga dimensi tersebut menjadi berlebihan.

\section{Deskripsi Kesesuaian Alumni}

Jumlah alumni yang mengembalikan kuesioner dalam penelitian ini adalah sebanyak 11 orang atau 46\% dari 24 lulusan program Magister Pendidikan Ekonomi PPs Unnes. Berdasarkan jenis pekerjaan, sebanyak 8 orang $(73 \%)$ lulusan bekerja sebagai guru, baik di sekolah swasta (25\% atau 2 orang) maupun di sekolah negeri ( $75 \%$ atau 6 orang). Sebanyak 3 orang (18\%) berprofesi sebagai dosen di jurusan Pendidikan Ekonomi FE Unnes, yaitu Kardiyem, Inaya Sari Melati, dan Kemal Budi Mulyono. Dari keterangan tersebut, maka dapat dikatakan bahwa banyak alumni yang bekerja di bidang pendidikan, baik sebagai guru maupun dosen. Berdasarkan jumlah gaji yang diterima terakhir, sebanyak $55 \%$ atau 6 orang menerima gaji sekitar Rp 1.500.000,00 s.d. Rp 3.500.000,00 dan sebanyak $45 \%$ atau 5 orang menerima gaji sebesar Rp 3.500.000,00 s.d. Rp 5.500.000,00.

Alumni juga diminta memberikan jawaban atas relevansi mata kuliah yang diterima saat kuliah dan proses pembelajaran dengan pekerjaan saat ini. Secara umum, alumni berpendapat sangat positif. Alumni menyatakan bahwa mata 
Tabel 2. Jawaban Responden terhadap Relevansi Mata Kuliah dan Proses Pembelajaran di Magister Pendidikan Ekonomi dengan Pekerjaan Saat ini

\begin{tabular}{|c|c|c|}
\hline No. & Item Pertanyaan & Rangkuman Jawaban Alumni \\
\hline 1. & $\begin{array}{l}\text { Relevansi materi yag } \\
\text { diperoleh selama kuliah di } \\
\text { Prodi Pendidikan Ekonomi } \\
\text { S2 PPs Unnes terhadap } \\
\text { pekerjaan sekarang }\end{array}$ & $\begin{array}{l}\text { - Materi inovasi pembelajaran, penulisan karya ilmiah } \\
\text { sangat berguna dalam pembuatan karya ilmiah untuk } \\
\text { publikasi ilmiah kenaikan pangkat. } \\
\text { - sangat relevan, tapi perlu diperdalam khususnya materi } \\
\text { non metodologi penelitian. } \\
\text { - Dapat menerapkan teori pada kuliah terhadap materi yang } \\
\text { diajarkan di sekolah. } \\
\text { - penerapan materi kuliah pembelajaran inovatif dalam } \\
\text { pembelajarn di kelas }\end{array}$ \\
\hline 2. & $\begin{array}{l}\text { Relevansi proses } \\
\text { pembelajaran yang dialami } \\
\text { selama kuliah di Prodi } \\
\text { Pendidikan Ekonomi S2 } \\
\text { PPs Unnes terhadap } \\
\text { pekerjaan sekarang }\end{array}$ & $\begin{array}{l}\text { - Proses pembelajaran yang memberi kesempatan } \\
\text { mahasiswa melatih keterampilan berkomunikasi secara } \\
\text { lisan dalam presentasi maupun tulisan sangat sesuai } \\
\text { dengan tuntutan pekerjaan. } \\
\text { - } \text { relevan, tapi perlu ditingkatkan proses diskusi dan } \\
\text { menghindari ceramah. } \\
\text { - sangat relevan, karena saya sbagai guru ekonomi sangat } \\
\text { terbantu dengan proses pembelajaran yang ada. } \\
\text { - sangat relevan, proses pembelajarannya sangat membantu } \\
\text { saya dalam mengembangkan ide/gagasan, strategi dan } \\
\text { kepercayaan diri dalam proses pembelajaran maupun } \\
\text { forum MGMP. }\end{array}$ \\
\hline
\end{tabular}

kuliah yang diterima saat kuliah beserta proses pembelajarannya sangat membantu pelaksanaan tugas sebagai guru atau dosen. Rangkuman jawaban alumni atas pertanyaan relevansi ini tampak pada Tabel 2.

Bagian berikutnya yang ditanyakan kepada alumni adalah mengenai usulan mata kuliah. Berdasarkan jawaban responden diketahui bahwa sebagian besar alumni mengusulkan mata kuliah kewirausahaan (studi kelayakan bisnis) dan metodologi penelitian serta publikasi ilmiah. Alumni juga memberikan masukan atas keterampilan yang diperlukan untuk meningkatkan daya saing lulusan program Magister Pendidikan Ekonomi PPs Unnes. Keterampilan berkomunikasi (public relation), keterampilan pengembangan teknologi pembelajaran, keterampilan berwirausaha, dan keterampilan meneliti serta publikasi ilmiah menjadi keterampilan yang banyak disarankan oleh alumni.

Kesesuaian kompetensi dengan pekerjaan yang digeluti sekarang alumni Program Studi Magister Pendidikan Ekonomi PPs Unnes menjadi bagian terakhir yang ditanyakan kepada responden (alumni). Dengan menggunakan rentang skor 1-5, alumni secara rata-rata memberikan skor 4,13 artinya sangat sesuai. Tabel 3 menunjukkan skor untuk masing-masing item kesesuaian yang ditanyakan.

\section{Deskripsi Kepuasan Pengguna Lulusan}

Penelitian ini juga mengukur tingkat kepuasan pengguna lulusan. Pengguna lulusan diminta untuk memberikan tanggapan terhadap sembilan (9) item atau jenis kemampuan yang dimiliki oleh alumni Program Studi Magister Pendidikan Ekonomi PPs Unnes. Selain itu, pihak pengguna lulusan juga diminta masukan atas kompetensi apa yang seharusnya dimiliki oleh lulusan yang sesuai dengan dunia kerja serta saran/masukan untuk perbaikan penyelenggaraan pendidikan pada program studi Magister Pendidikan Ekonomi PPs Unnes (bisa terkait kurikulum, fasilitas, penguasaan teknologi informasi, dan lain sebagainya). Tabel 4 berikut ini menunjukkan hasil tanggapan pengguna lulusan atas kompetensi yang dimiliki oleh lulusan prodi Magister Pendidikan Ekonomi PPs Unnes. Integritas menjadi kemampuan yang paling tinggi dimiliki oleh alumni, yaitu mendapatkan skor 3,63 atau sangat baik. Kemampuan bahasa asing menjadi kemampuan yang memperoleh skor paling rendah, yaitu hanya sebesar 2,50 atau cukup baik. Rentang skor adalah 1-4. 
Tabel 3. Kesesuaian Kompetensi dengan Pekerjaan yang Digeluti Sekarang Alumni Program Studi Magister Pendidikan Ekonomi PPs Unnes

\begin{tabular}{|c|c|c|c|}
\hline No. & Item Kesesuaian Kompetensi & Skor & Keterangan \\
\hline 1. & $\begin{array}{l}\text { Dalam pekerjaan yang anda geluti sekarang, anda mampu } \\
\text { mengaplikasikan bidang keahlian yang didapatkan ketika } \\
\text { kuliah di Magister Pendidikan Ekonomi PPs Unnes. }\end{array}$ & 4,50 & Sangat Bisa \\
\hline 2. & $\begin{array}{l}\text { Relevansi materi yang didapatkan di Magister Pendidikan } \\
\text { Ekonomi PPs Unnes dapat memenuhi standar dalam pekerjaan } \\
\text { yang anda geluti sekarang. }\end{array}$ & 4,13 & Sangat Memenuhi \\
\hline 3. & $\begin{array}{l}\text { Materi yang didapatkan di Magister Pendidikan Ekonomi PPs } \\
\text { Unnes (baik teoretis maupun praktis) dapat membantu anda } \\
\text { ketika beradaptasi dengan lingkup pekerjaan yang anda geluti } \\
\text { sekarang. }\end{array}$ & 4,13 & Sangat Membantu \\
\hline 4. & $\begin{array}{l}\text { Materi yang didapatkan di Magister Pendidikan Ekonomi PPs } \\
\text { Unnes (baik teoretis maupun praktis) dapat membantu anda } \\
\text { ketika menganalisa masalah yang dihadapi oleh diri sendiri } \\
\text { maupun organisasi dalam pekerjaan. }\end{array}$ & 4,00 & Membantu \\
\hline 5. & $\begin{array}{l}\text { Materi yang didapatkan di Magister Pendidikan Ekonomi PPs } \\
\text { Unnes (baik teoretis maupun praktis) dapat membantu anda } \\
\text { dalam memberikan alternatif pemecahan masalah yang } \\
\text { dihadapi oleh organisasi atau diri sendiri. }\end{array}$ & 4,00 & Membantu \\
\hline 6. & $\begin{array}{l}\text { Materi yang didapatkan di Magister Pendidikan Ekonomi PPs } \\
\text { Unnes (baik teoretis maupun praktis) dapat membantu anda } \\
\text { ketika mengambil keputusan dalam pekerjaan yang anda geluti. }\end{array}$ & 4,13 & Sangat Membantu \\
\hline 7. & $\begin{array}{l}\text { Materi yang didapatkan di Magister Pendidikan Ekonomi PPs } \\
\text { Unnes (baik teoretis maupun praktis) dapat menunjang } \\
\text { pekerjaan anda dalam mencapai visi dan misi organisasi secara } \\
\text { keseluruhan. }\end{array}$ & 4,00 & Membantu \\
\hline
\end{tabular}

Pengguna lulusan memberikan masukan kepada pengelola prodi, diantaranya; perbaikan fasilitas umum yang ada di kampus seperti MCK dan parkir, perbaikan kurikulum, dan peningkatan sosialisasi dan publikasi prodi melalui website. Sosialisasi informasi peningkatan program pendidikan melalui website Unnes. Materi perkuliahan dilengkapi dengan kompetensi yang dibutuhkan untuk pengembangan diri sebagai guru misalnya membuat penelitian tindakan kelas, artikel, modul, alat peraga.

\section{Analisis Kepuasan Mahasiswa dengan Metode IPA}

Analisis kepuasan mahasiswa atas layanan yang diberikan dilakukan dengan menggunakan perhitungan indeks kepuasan mahasiswa dan analisis Importance-Performance Analysis. Hasil perhitungan indeks kepuasan mahasiswa menunjukkan bahwa layanan yang diberikan sudah dianggap memuaskan walaupun nilainya sangat mendekati "kurang memuaskan". Terdapat dua dimensi layanan yang memperoleh skor terendah, yaitu dimensi acces dan dimensi understanding customer. Artinya, kedua dimensi ini dianggap kurang memuaskan oleh mahasiswa, sedangkan dua dimensi yang memperoleh skor tertinggi tangible dan courtesy merupakan dua dimensi yang dianggap mahasiswa telah diberikan layanan yang memuaskan. Berdasarkan perhitungan persentase kualitas kepuasan yang diterima mahasiswa menunjukkan bahwa layanan yang diberikan masih tergolong rendah, hanya sebesar $62,65 \%$. Artinya, secara umum Prodi harus memperbaiki layanan secara menyeluruh untuk semua dimensi.

Hasil analisis Importance-Performance Analysis memberikan analisis yang lebih komprehensif dan mendalam. Analisis IPA tidak hanya berpedoman pada skor layanan yang diberikan oleh mahasiswa, tetapi juga membandingkan apa yang seharusnya dengan apa yang telah diterima. Artinya, dengan analisis IPA dapat menentukan dimensi mana yang harus diperbaiki segera atau diperbaiki tetapi dengan prioritas rendah. Skor yang rendah bukan berarti dimensi layanan tersebut harus segera diperbaiki. Mahasiswa mungkin tidak menganggap penting dimensi layanan terse- 
Tabel 4. Tanggapan Pihak Pengguna Lulusan

\begin{tabular}{clcc}
\hline No. & \multicolumn{1}{c}{ Jenis Kemampuan } & Skor & Keterangan \\
\hline 1 & Integritas (etika dan moral) & 3,63 & Sangat baik \\
2 & Keahlian berdasarkan bidang ilmu (profesionalisme) & 3,38 & Sangat baik \\
3 & Keluasan wawasan antar disiplin ilmu & 3,13 & Sangat baik \\
4 & Kepemimpinan & 3,25 & Sangat baik \\
5 & Kerjasama dalam tim & 3,38 & Sangat baik \\
6 & Bahasa asing & 2,50 & Cukup baik \\
7 & Komunikasi & 3,38 & Sangat baik \\
8 & Penggunaan teknologi informasi & 3,25 & Sangat baik \\
9 & Pengembangan diri & 3,38 & Sangat baik \\
\hline & Rata-rata & $\mathbf{3 , 2 5}$ & Sangat baik \\
\hline
\end{tabular}

but, sehingga skor yang rendah tidak menjadi masalah untuk segera diperbaiki.

Hasil analisis IPA menunjukkan bahwa dimensi acces dan dimensi reliability berada pada kuadran A. Kuadran A menunjukkan dimensi layanan yang sangat penting namun belum diberikan layanan dengan kualitas yang terbaik artinya harus segera diperbaiki. Dimensi acces menunjukkan tingkat kemudahan pihak penyedia jasa untuk dihubungi atau ditemui oleh konsumen. Dengan demikian, mahasiswa menganggap bahwa pegawai atau karyawan di bagian administrasi tidak mudah untuk ditemui. Hal ini bisa dikarenakan saat mahasiswa membutuhkan layanan, pegawainya sedang keluar atau sedang mengerjakan tugas di tempat lain atau memang karena karyawannya yang sering tidak ada di ruang layanan. Pengelola harus mengambil kebijakan untuk segera memperbaiki dimensi layanan ini dengan cara melakukan monitoring secara periodik untuk memantau keberadaan petugas atau karyawan di ruang layanan (administrasi).

Dimensi reliability meliputi kemampuan pihak menyedia jasa dalam memberikan jasa atau layanan secara cepat dan akurat sehingga konsumen dapat mempercayai dan mengandalkannya. Mahasiswa menganggap bahwa petugas atau admisi belum bisa memberikan layanan yang baik, yaitu memberikan layanan dengan cepat dan akurat. Mahasiswa menganggap bahwa admisi tidak dapat dipercayai dan diandalkan. Hal ini sangat tidak baik jika dibiarkan. Oleh karena itu, pengelola prodi harus segera mengambil tindakan perbaikan. Upaya yang dapat dilakukan adalah meningkatkan kemampuan dan kompetensi petugas layanan untuk bisa mengerjakan layanan dengan cepat dan akurat melalui pengiriman petugas ke pelatihan atau bimbingan teknis layanan.
Upaya lainnya adalah dengan memberikan pelatihan intensif (in house training) dengan menghadirkan pakar.

Prodi telah menunjukkan layanan yang berkualitas baik pada ketiga dimensi layanan lainnya, yaitu dimensi courtesy, dimensi credibility, dan dimensi tangible. Pengelola prodi diharapkan dapat mempertahankan prestasi ini atau mungkin dapat meningkatkan lebih baik lagi. Dimensi courtesy menunjukkan etika kesopanan, rasa hormat, dan keramahan pihak penyedia jasa. Dimensi credibility adalah kejujuran dan tanggung jawab pihak penyedia jasa. Dan dimensi tangible meliputi penampilan dan performansi dari fasilitas fisik, peralatan, personel, dan material komunikasi yang digunakan dalam proses penyampaian layanan. Mahasiswa menganggap ketiga dimensi ini dan telah memperoleh layanan dengan kualitas yang baik. Artinya, petugas layanan merupakan petugas yang jujur dan penuh tanggung jawab, petugas yang ramah, sopan dan mempunyai rasa hormat yang baik. Di samping itu, sarana prasarana untuk memberikan layanan telah dianggap memenuhi atau baik. Oleh karena itu, pengelola prodi harus mempertahankan prestasi ini.

Perbaikan kualitas pelayanan akan berjalan dengan baik jika ditunjang dengan kepemimpinan yang mendukung. Kepemimpinan dalam hal ini adalah ketua prodi dan direksi PPs harus mampu menciptakan budaya pelayanan yang baik dengan memberikan contoh, motivasi, monitoring, dan kesempatan berkembang bagi karyawan. Hal ini sesuai dengan pendapat Trivellas dan Dargenidou (2009). Ia membuktikan pemimpin yang inovatif dan melaksanakan monitoring yang dapat memberikan jaminan pemberian kualitas pelayanan oleh karyawan kepada mahasiswa. 
Penggunaan konsep IPA telah mendukung pendapat Angell et al. (2008) yang menyatakan bahwa IPA merupakan alat yang tepat untuk mengukur kualitas pelayanan pada program magister. Instrumen kualitas pelayanan yang dikembangkan dalam penelitian ini mengacu pada Parasuraman et al. (1994) yang lebih tepat untuk korporasi. Dalam setting dunia pendidikan, pengukuran kualitas pelayanan perlu mencoba untuk menggunakan instrumen lain seperti yang disarankan oleh Brochado (2009) seperti SERVPERF, SERVQUAL, importance-weighted SERVPERF, importanceweighted SERVQUAL and HEdPERF. Ramseook-Munhurrun et al. (2010) mengembangkan EDUSERV untuk mengukur kualitas pelayanan dalam setting dunia pendidikan. Sementara itu, Jain et al. (2011) menyodorkan model baru dalam pengukuran kualitas pelayanan yang terdiri dari dua dimensi utama yaitu program quality dan quality of life. Program quality mencakup kurikulum, interaksi industri, kualitas input, fasilitas akademik. Quality of life mencakup proses nonakademik, fasilitas pendukung, kampus, dan kualitas interaksi.

\section{Analisis Kesesuaian Alumni}

Berdasarkan hasil penelitian mengenai kesesuaian alumni diperoleh informasi bahwa hampir semua alumni telah bekerja sesuai dengan visi-misi prodi Magister Pendidikan Ekonomi PPs Unnes. Alumni telah bekerja di bidang pendidikan, baik sebagai guru, dosen, atau lainnya dengan variasi gaji berada pada kisaran Rp 1.500.000,00 - Rp 5.500.000,00. Alumni memang telah bekerja sebelum melanjutkan studi S2, namun terdapat alumni yang sebelumnya masih fresh graduate. Dengan demikian, hal ini wajar jika alumni secara umum menyatakan bahwa materi yang diperoleh dan proses pembelajarannya relevan dengan bidang pekerjaannya masing-masing. Alumni masih mengharapkan perbaikan kualitas proses pembelajaran yang mendidik mahasiswa untuk mampu melatih kemampuan berkomunikasi di depan umum dan juga kemampuan dalam melakukan penelitian dan publikasi. Oleh karena itu, pengelola prodi diharapkan dapat mengambil kebijakan untuk menekankan pentingnya kemampuan berkomunikasi dan meneliti. Upaya yang dapat diambil adalah menelaah kembali pendekatan pembelajaran yang dilakukan oleh para dosen pengampu. Apalagi Unnes telah menyusun kurikulum baru, yaitu kurikulum 2015 yang menekankan proses perkuliahan berpusat pada aktivitas mahasiswa. Upaya lainnya adalah menelaah learning outcome lulusan terkait dengan kemampuan komunikasi dan meneliti serta mempublikasikannya di forum ilmiah.

Hal yang menarik adalah mengenai masukan alumni terkait dengan usulan mata kuliah. Paling tidak terdapat tiga pokok mata kuliah yang diberikan tekanan oleh mahasiswa, yaitu mata kuliah bisnis dan wirausaha, penelitian dan publikasi ilmiah, dan materi bidang studi ekonomi/ akuntansi. Pengelola prodi dapat melakukan kajian mengenai kurikulum yang selama ini berlaku termasuk kurikulum yang baru saja disusun (Kurikulum 2015) untuk perbaikan sesuai masukan dari alumni. Mata kuliah bisnis dan wirausaha mungkin tidak harus nampak pada satu mata kuliah sendiri, namun bisa masuk ke dalam mata kuliah lainnya yang relevan. Kemampuan meneliti telah diasah pada mata kuliah metodologi penelitian dan seminar rancangan tesis. Pengelola prodi bisa memberikan kemampuan publikasi ilmiah melalui penugasan secara terstuktur dan bersifat individual. Atau, bisa menjadi syarat keluarnya nilai jika mahasiswa mampu mempublikasikan karya tulis ilmiah pada forum ilmiah (seminar, konferensi) nasional. Atau kebijakan lainnya, yaitu syarat ujian tesis, mahasiswa sudah melakukan publikasi karya tulisnya pada forum ilmiah atau jurnal ilmiah nasional.

Kesesuaian kompetensi dengan pekerjaan yang digeluti sekarang oleh alumni Program Studi Magister Pendidikan Ekonomi PPs Unnes termasuk tinggi, bisa dilihat pada tabel 4.6. di atas. Artinya proses pembelajaran telah memberikan bekal yang cukup bagi lulusan untuk meningkatkan kompetensi khususnya pada bidang pendidikan ekonomi. Alumni sangat bisa mengaplikasikan bidang keahlian masing-masing pada pekerjaannya. Hal ini mungkin juga dikarenakan alumni telah bekerja sebelumnya, artinya pada saat kuliah, alumni tersebut tinggal meningkatkan kompetensi yang dimiliki sebelumnya. Prodi berhasil untuk menstimulus mahasiswa untuk mampu meningkatkan kompetensinya.

Namun demikian, terdapat dua hal yang perlu diperhatikan oleh pengelola yaitu kemampuan menganalisis masalah dan kemmpuan memberikan alternatif pemecahan masalah tersebut. Walaupun alumni telah menganggap membantu, skornya terendah daripada item lainnya. Artinya, alumni ingin memberikan masukan 
kepada pengelola prodi agar mampu meningkatkan kualitas pembelajaran yang mampu mengajak mahasiswa mengasah kemampuan analisis terhadap permasalahan di lingkungan sekitar dan mampu memecahkannya. Kompetensi yang sangat penting untuk dimiliki agar alumni mampu berkontribusi lebih pada lingkungan pekerjaan dan lingkungan masyarakatnya masing-masing. Upaya yang dapat ditempuh oleh pengelola prodi adalah memperbaiki proses pembelajaran dengan mengimplementasikan Kurikulum 2015. Proses pembelajaran yang mengajak mahasiswa untuk meningkatkan kemampuan berfikir tingkat tinggi (Higher Order Thinking Levels) bukan hanya kemampuan berfikir tingkat rendah (Lower Order Thinking).

\section{Analisis Kepuasan Pengguna Lulusan}

Terdapat dua hal penting yang ditanyakan kepada pengguna lulusan dalam penelitian ini, yaitu tanggapan pengguna alumni terhadap kompetensi lulusan dan masukan untuk pengelola prodi. Hasil penelitian menunjukkan bahwa secara rata-rata pengguna lulusan berpendapat bahwa lulusan memunyai kemampuan yang sangat baik. Jenis kemampuan yang dinilai adalah integritas (etika dan moral), keahlian berdasarkan bidang ilmu (profesionalisme), keluasan wawawasan antar disiplin ilmu, kepemimpinan, kerjasama dalam tim, bahasa asing, komunikasi, penggunaan teknologi informasi, dan pengembangan diri. Terdapat dua kemampuan yang diberikan skor rendah oleh pengguna lulusan, yaitu kemampuan keluasan wawasan antar disiplin ilmu dan kemampuan bahasa asing. Pengguna lulusan masih "belum puas" terhadap dua kemampuan tersebut. Keluasan wawasan antardisiplin ilmu memang kemampuan yang tidak mudah dikuasai secara umum. Lulusan membutuhkan waktu dan penggemblengan yang kuat untuk bisa menguasai kemampuan ini.

Demikian juga kemampuan bahasa asing (dalam hal ini adalah bahasa Inggris) yang tidak dapat dengan cepat untuk dikuasai. Upaya yang dapat diambil oleh pengelola prodi adalah mendesain proses perkuliahan yang mampu mengajak mahasiswa untuk berpikir komprehensif dalam menyelesaikan satu permasalahan. Mahasiswa tidak diminta hanya memandang satu kasus dari perspekstif ekonomi saja, namun mengkaitkan bidang ilmu lainnya. Prodi juga harus mendorong mahasiswa untuk mau dan mampu menguasai bahasa asing. Keberadaan mata kuliah bahasa Inggris selama ini belum optimal dan tidak akan mampu meningkatkan secara cepat. Mahasiswa diharapkan dapat meningkatkannya dengan melakukan kegiatan otodidak atau mengambil kursus dan pelatihan.

Pengguna lulusan juga diminta masukan untuk perbaikan kualitas penyelenggaraan pendidikan. Pengguna lulusan memberikan masukan antara lain perbaikan fasilitas dan peningkatan kualitas kurikulum. Perbaikan kurikulum merupakan hal pokok karena akan berpengaruh pada proses perkuliahan. Kurikulum merupakan jantung dalam proses belajar mengajar. Jadi, sangat tepat jika pengguna lulusan memberikan masukan perbaikan kualitas kurikulum. Pengelola prodi dapat menempuh upaya pengembangan kurikulum untuk mendapatkan hasil yang optimal. Pengelola prodi telah melakukannya sebelum semester Gasal 2015/2016 untuk menyusun kurikulum 2015. Pengembangan kurikulum di Unnes dilakukan secara periodik dengan melibatkan stakeholders prodi, yang meliputi dosen, mahasiswa, pengguna lulusan, pakar kurikulum, dan masyarakat umum. Upaya perbaikan fasilitas, khususnya MCK dan parkir telah dilakukan oleh pengelola PPs secara keseluruhan. Namun dalam kenyataannya masih dianggap kurang maksimal. Pemeliharaan gedung dan fasilitas MCK harus dilakukan dengan baik. Pengelola PPs telah menambah tenaga kebersihan (cleaning service) untuk menjamin kebersihan dan kelayakan fasilitas MCK.

\section{SIMPULAN}

Hasil analisis kepuasan layanan menggunakan Importance-Performance Analysis terdapat dua dimensi layanan yang harus menjadi prioritas utama untuk segera diperbaiki, yaitu dimensi acces dan reliability. Bidang pekerjaan alumni telah sesuai dengan visi misi prodi dan alumni berpendapat bahwa materi dan proses perkuliahan sangat relevan dengan bidang pekerjaan yang digeluti sekarang sehingga sangat membantu menyelesaikan pekerjaan. Kepuasan pengguna terhadap kompetensi lulusan termasuk dalam kategori sangat bagus dan pengguna lulusan memberikan masukan kepada pengelola prodi pada aspek kualitas kurikulum dan fasilitas penunjang (MCK dan parkir).

Saran yang dapat diberikan berdasarkan hasil dan pembahasan penelitian ini adalah Pengelola prodi dapat memberikan perhatian lebih 
(prioritas utama) untuk meningkatan kualitas layanan pada dimensi acces (kemudahan menghubungi petugas layanan) dan dimensi reliability (kemampuan petugas layanan untuk melaksanan dengan cepat dan akurat). Hal yang bisa dilakukan adalah dengan kegiatan monitoring dan evaluasi secara periodik (tiga pekanan) dan pelaksanaan pelatihan bagi petugas layanan. Upaya perbaikan kualitas fasilitas penunjang (MCK dan Parkir) seperti yang telah diberikan masukan oleh pengguna alumni juga harus dilakukan.

\section{UCAPAN TERIMA KASIH}

Terima kasih kami ucapkan kepada Program Pascasarjana Unnes yang telah memberikan dana dalam pelaksanaan penelitian. Terimakasih kepada mahasiswa, alumni, dan pengguna lulusan yang telah berkenan menjadi narasumber. Terima kasih juga disampaikan kepada Dewan Redaksi Jurnal Cakrawala Pendidikan yang telah memberi saran yang berharga bagi perbaikan artikel ini sehingga dapat dipublikasikan.

\section{DAFTA PUSTAKA}

Algifari. 2013. Statistika Induktif untuk Ekonomi dan Bisnis. Yogyakarta: UPP STIM YKPN.

Algifari. 2015. Mengukur Kualitas Layanan dengan Indeks Kepuasan, Metode Importance-Performance Analysis (IPA) dan Model Kano. Yogyakarta: Kurnia Kalam Semesta.

Angell, Robert J., Troy W. Heffernan and Phil Megicks. 2008. "Service Quality in Postgraduate Education." Quality Assurance in Education, Vol. 16 Iss 3 pp. 236-254.

Brochado, Ana. 2009. "Comparing Alternative Instruments to Measure Service Quality in Higher Education." Quality Assurance in Education, Vol. 17 Iss 2 pp. 174-190.

Dirwan A. 2014. Pengaruh Kualitas Pelayanan dan Komitmen Mahasiswa terhadap Motivasi Berprestasi Mahasiswa Perguruan Tinggi Swasta. Cakrawala Pendidikan, Oktober 2014, Th. XXXIII, No. 3, Hal. 379-391.

Jain, Rajani, Gautam Sinha dan Sangeeta Sahney. 2011. "Conceptualizing Service Quality In
Higher Education." Asian Journal on Quality, Vol. 12 Iss 3 pp. $296-314$.

Martila, J. A., dan James, J. C. 1977. “ImportancePerformance Analysis." Journal of Marketing, Vol. 2 No. 1 Hal. 77-79.

Muzakiyah, Siti Husna Ainu Syukri, dan Ira Setyaningsih. 2011. "Analisis Kualitas Pelayanan Pada Bagian Tata Usaha Berdasarkan Tingkat Kepuasan Mahasiswa." Jurnal Ilmiah Teknik Industri, Vol. 10, No. 1, Juni 2011. Jurusan Teknik Industri, Universitas Islam Negeri Sunan Kalijaga Yogyakarta.

Ong, Johan Oscar dan Jati Pambudi. 2014. "Analisis Kepuasan Pelanggan Dengan Importance Performance Analysis Di SBU Laboratory Cibitung PT Sucofindo (Persero).”J@TI Undip, Vol IX, No 1, Januari 2014. Undip Semarang.

Parasuraman, A., Zeithaml V. A., dan Berry L. L. 1994. "Servqual: Alternative Scales for Measuring Service Quality? A Comparative Assessment Based on Psychometric and Diagnostic Criteria." Journal of Retailing, Vol. 70, No. 1, hal. 193-199.

Primiani C. Novi dan D. Wahyu Ariani. 2005. "Total Quality Management dan Service Quality dalam Organisasi Pendidikan Tinggi." Cakrawala Pendidikan, Juni 2005, Th. XXIV, No. 2, Hal. 177-198.

Ramseook-Munhurrun, Prabha, Perunjodi Naidoo, dan Pushpa Nundlall. 2010. “A Proposed Model For Measuring Service Quality In Secondary Education." International Journal of Quality and Service Sciences, Vol. 2 Iss 3 pp. $335-351$.

Rifandi, Ahmad. 2013. "Mutu Pembelajaran dan Kompetensi Lulusan Diploma III Politeknik." Cakrawala Pendidikan, Februari 2013, Th. XXXII, No. 1, Hal. 125-138.

Sharabi, Moshe. 2013. "Managing and Improving Service Quality In Higher Education." International Journal of Quality and Service Sciences, Vol. 5 Iss 3 pp. $309-320$. 
Silva, Fatima dan Paula Odete Fernandes. 2012. "Empirical Study on the Student Satisfaction in Higher Education: Importance-Satisfaction Analysis." International Scholarly and Scientific Research \& Innovation Vol. 6 No. 6 pp 1075-1080.

Sudirman, Rio. 2010. Analisis Pengaruh Kualitas Pelayanan terhadap Kepuasan Mahasiswa dan Citra Perguruan Tinggi. Diperoleh dari http://untag-banyuwangi.ac.id/attachments/article/347/ANALISIS $\% 20 \% 20$ PENGARUH $\% 20 \% 20$ KUALITAS $\% 20$ PELAYANAN\%20TERHADAP\%20 KEPUASAN\%20.pdf. (Diakses tanggal 18 Maret 2015).
Supranto, J. 2006. Pengukuran Tingkat Kepuasan Pelanggan untuk Menaikkan Pangsa Pasar (Cet. III). Jakarta: Rineka Cipta.

Supriyanto, Achmad. 2011. "Implementasi Total Quality Management dalam Sistem Manajemen Mutu Pembelajaran." Cakrawala Pendidikan, Februari 2011, Th. XXX, No. 1, Hal. 17-29.

Trivellas, Panagiotis and Dimitra Dargenidou. 2009. "Leadership And Service Quality in Higher Education; The Case of the Technological Educational Institute of Larissa." International Journal of Quality and Service Sciences, Vol. 1 Iss 3 pp. 294-310. 